The needs of Nigeria for medical services are totally different from those of Britain. It is unreasonable to assume that the standards of attainment for Nigerians practising in Nigeria must be the same as those of Englishmen practising in England. Also, in Nigeria to-day there is one doctor to every 40,000 people (as compared with a ratio of $1: 1,000$ in Britain) so that there is a tremendous need to increase the output of doctors. Specifically, the Commission makes three main recommendations ; (a) doubling the output of the University College Hospital, Ibadan ; $(b)$ instituting a locally recognized examination, for those who fail to qualify for the medical degree at Ibadan; (c) re-orientating the medical courses to emphasize public health, preventive medicine and pædiatrics.

The Commission was favourably impressed with the state of agricultural (degree) courses at the University College, Ibadan; but the flow of graduates (20 a year) is pitifully inadequate to meet the nation's need of 200 a year.

So far as the siting of new universities is concerned, the Commission proposes that there should be four large universities, one in each of the three Regions and one in Lagos, the federal capital, rather than a number of smaller universities. These universities should be independent of one another; they should be national institutions with all three Regions equally represented on their governing bodies; and they should be financed largely from federal funds on the advice of a national universities commission.

It is recommended that the three regional branches of the Nigerian College of Arts, Science and Technology should become centres of university education. The Ibadan branch would be joined to the adjacent
University College, Ibadan. The branch at Enugu, in the Eastern Region, would become part of the new University of Nigeria, at Nsukka. It would be used to develop departments of engineering, metallurgy, surveying and the social sciences, and also be the headquarters of an institute of education. The Zaria branch of the Nigerian College would become the centre of a university in the Northern Region, which would also embrace the Ahmadu Bello College of Arabic Studies, at Kano, and the Veterinary Research Institute at Vom. A particular proposal about this new university in the Northern Region is that opportunity should be given for undergraduates to read combinations of subjects drawn from different disciplines.

The University at Lagos would be an unusual type of institution, which would be non-residential, and would have three main departments. These would be a School of Commerce and Business Administration, offering both day and evening courses, a School of Economics and Social Studies, and a Department for Correspondence Courses. Although this would offer only a limited range of courses, it is believed that it would encourage large numbers of men and women, who would otherwise not have the opportunity, to improve their education and fit them for more responsible posts.

This is an outline of the Commission's main proposals. What it recommends is a stupendous undertaking, and will cost large sums of money. The Nigerian people will have to forgo other things they want, so that every available penny is invested in education. Even this will not be enough. In the words of the report, "Nigerian education must for a time become an international enterprise".

\title{
VERTEBRATE LOCOMOTION
}

\begin{abstract}
A SYMPOSIUM on "Vertebrate Locomotion", the fifth in the series sponsored by the Zoo. logical Society of London, was held at the rooms of the Society on Wednesday, November 9, 1960.

Sir James Gray opened the meeting with a paper on the general principles involved in studying the mechanics of vertebrate movement. $\mathrm{He}$ stressed the difficulty of providing an exact treatment of the problems of aquatic and aerial locomotion and gave examples from his own work and that of his students on these and on the more amensble problems of tetrapod movement. Here, exact measurement of forces exerted by the limbs on the substratum provided a basis for analysing the locomotor system; from these results it was demonstrated that the muscular system must be treated as a single integrated whole.

Dr. R. Bainbridge, after enumerating and commenting on the many still unsolved problems in fish locomotion, concentrated on one of these-the relationship of power output, in terms of known data for muscle, to drag, calculated on various simple assumptions.

He showed that within the wide range of experim. entally established estimates for the power output of different vertebrate and invertebrate muscles, it was possible to account for the observed steady speeds of progression of most small fish as well as of whales and dolphins without the need to assume
\end{abstract}

completely laminar flow over the body surface. A surprising exception was provided by the barracuda.

Dr. G. M. Jarman contributed a brief note on the form of intermuscular bones and myocommata in the fish myotome. He suggested that the conical surface of a myocomma is inclined at such an angle to the longitudinal (contractile) axis of the muscle that the connective tissue mass does not change in area or thickness and therefore waste the contractile effort of the muscle.

Mr. E. H. Watts gave an account of some experiments in designing ships on lines which imitated certain features in fast-swimming fish. Perhaps the most significant of these practical exercises was the provision of lateral keels on either side of the stern, similar to those found in scombroid fishes and certain sharks. These structures slightly increased the propulsive efficiency and greatly reduced the minimum turning circle of the vessel. A more surprising result, which did not appear explicable on the models of fish locomotion described earlier by Dr. Bainbridge, was that the artificial creation of turbulent flow along the hull form appeared in some ships actually to increase the propulsive efficiency by reducing the drag.

The considerable variation in form and flexibility of the sacro-iliac joint in the anuran amphibian was described by Dr. H. P. Whiting. In Xenopus and 
Discoglossus respectively, longitudinal sliding and horizontal rotation of the pelvis on the vertebral column are very marked; Rana shows the more commonly known rotation in a vertical plane. The different motions are consistent with observed differences in body movement of the normal animals, and suggest that an important shock-absorbing property, as well as a possible locomotory contribution, is provided by the musculature of the sacro-iliac joint.

Dr. K. M. Backhouse described the fish-like lateral motion of the hind feet of the seal when swimming in water; and contrasted this with the movement on land, where progression is achieved by dorsoventral flexion of the trunk coupled with a hitching action of the fore limbs. Slow-motion films illustrated the terrestrial locomotion, in which the highly flexible metacarpophalangeal and interphalangeal joints of the fore limb play an important part.

Prof. E. J. Slijper, of Amsterdam, gave an account, also illustrated by film, of locomotion and locomotory organs in whales and dolphins. An interesting point to which he directed attention was the fact that cruising speed and maximum speed of the small dolphins was about the same as that for the much larger whales. He suggested that this could be explained partly by the better mechanical organization of musculature in dolphins, but also on the assumption that the flow of water over the body surface of the dolphin was almost wholly laminar, while it was partly turbulent in whales.

The power of the flying bird was discussed by Dr. R. H. J. Brown. He surveyed the various attempts to estimate this from the earliest date of Lilienthal to the more recent figures based on windtunnel tests, oxygen consumption figures and gliding parameters of birds in actual flight. These data suggest that the aerodynamic efficiency and the muscle-power must be very high even in normal sustained flight; greatly increased power must be available for take-off and climbing.

Terrestrial locomotion of dogs and horses was dealt with by Prof. C. W. Ottaway, who described the highly co-ordinated and integrated action of limb and shoulder muscles in the normal walking stride, and illustrated the value of nerve section and tenotomy as a method of studying the role of individual muscles.

Finally, a contribution on arboreal mammals by Dr. J. R. Napier reviewed the evolution of prehensility in the primate hand. The inward turning of the thumb which characterized true opposability required a deep carpal tunnel brought about by the set of trapezium and scaphoid, together with the existence of a saddle joint at the carpo-metacarpal articulation. True opposability is only attained in Old World monkeys, and was evolved fairly late in primate history.

The symposium was well attended, and the discussion which followed each session, though necessarily brief, raised a number of interesting points made from personal observation on locomotory behaviour as well as on the theoretical principles involved. It was fittingly concluded by the showing of a film, still in its partially edited condition, from the Zoological Society's television unit, demonstrating various modes of running and jumping by man and by enimals from the collection. The slow-motion sequences collected together in the film, which was introduced by Dr. Fay Hall, were particularly interesting and instructive. JOHN E. HARRIS

\section{OBITUARIES}

Prof. W. J. Duncan, C.B.E., F.R.S.

Wiclitam Jolly Duncan, Mechan professor of aeronautics and fluid mechanics in the University of Glasgow, died on December 9 at the age of sixty-six. He had a very varied experience. Born on April 26, 1894, he was the son of Robert Duncan, M.P., senior partner of Ross and Duncan, engineers, of Glasgow. He was educated at Dulwich College and the University of London. He served in both World Wars, during the First in France and Flanders and later at the Aircraft Inspection Directorate. In the Second World War he worked for a time at the Royal Aircraft Establishment, and then as head of the Air Defence Research Establishment at Exeter. In 1945 he was sent to the Luftfahrtforschungsanstalt Hermann Göring, at Völkenrode, to supervise the disposal of German aeronautical equipment. $\mathrm{H} \theta$ married in 1936 the daughter of G. S. Baker, who was then superintendent of the William Froude Ship Tank at the National Physical Laboratory, and had a family of four-all girls.

Duncan was appointed to the scientific staff of the Aerodynamics Division, National Physical Laboratory in 1926, and it was there that $I$, superintendent of the Division, first came to know him. In his work there, he was closely associated with the late Dr. R. A. Frazer, and A. R. Collar, now professor of aeronautical engineering in the University of Bristol. This team of three scientists was entrusted with the investigation of the new problem of aircraft flutter, a problem they were able to solve fairly completely, and in particular to lay down design rules whereby flutter could be avoided. In the process they greatly developed the theory of matrices, and together wrote a book, "Elementary Matrices", published in 1938, which has been reprinted four times and is a standard work on the subject. In 1934 Duncan left the National Physical Laboratory to become the first head of the Department of Aeronautics at Hull, and in 1938 he was made the first Wakefield professor there.

At the end of the War a group of four was entrusted with the search for a suitable site for the proposed new College of Aeronautics; Duncan and I were two of these, and we both became very interested in this revolutionary new idea in postgraduate training. When the College was eventually established at Cranfield, I became its first principal and Duncan was appointed professor of aerodynamics, and became also deputy principal three years later. I can say with certainty that the major part in the formulation of the teaching methods to be adopted in the new College was due to Duncan. It was during this period that he and I made arrangements with the Cambridge University Press for a series of aeronautical books, and Duncan's work on "Control and Stability of Aircraft" was the first of this series. Incidentally, 